$\mathrm{S}$ in abandonar el convencimiento de que ante los cambios y conflictos sociales que vive el mundo y frente a los cuales los estudiosos del Derecho no podemos desentendernos ni permanecer indiferentes, se exige profundizar en la investigación para responder a una sociedad dinámica y cambiante con propuestas de adecuación del ordenamiento jurídico, acordes con las nuevas realidades. Por ende, y con tal propósito, este primer semestre del 2014 estamos entregando a nuestros lectores el número 19 de la revista DIXI, cuando celebramos los veinte años de la Facultad de Derecho de la Universidad Cooperativa de Colombia, sede Bucaramanga.

Creemos que la presente edición de la revista contiene valiosos escritos que responden al corolario del estudio juicioso y abnegado de sus autores, quienes intuyen la importancia de las transformaciones en el mundo del conocimiento, y aceptan que la ciencia jurídica debe hacer transversal diferentes disciplinas para responder a los problemas de la cotidianidad. Ellos, los articulistas, saben que la investigación de la mano de la docencia ayuda a desmitificar la idea de que el Derecho es solo norma. Por el contrario, lo conciben frente a los contextos sociales, económicos, políticos y culturales que determinan su creación. Así es como ustedes, respetados lectores, podrán disfrutar de diferentes documentos escritos con profesionalismo y como una contribución a la razón de ser de la educación superior: ahondar en el conocimiento.

Como investigadora y colaboradora internacional de la revista, contamos con la participación de Gabriela Ulas de la Universidad de Buenos Aires y de la Universidad de Belgrano, ambas en Buenos Aires (Argentina). Su artículo "La responsabilidad del profesional en los delitos tributarios y la imputación objetiva" constituye un análisis cuidadoso sobre la actuación del profesional del derecho ante la evasión fiscal y el delito tributario.

El texto titulado "Estado actual de los mecanismos para la solución de conflictos contractuales en el Estado colombiano", de las investigadoras de la Universidad Pontificia Bolivariana, sede Bucaramanga, Lina Marcela Reyes-Sarmiento y Sara Patricia Guzmán-Suárez, analiza la conciliación, mecanismo alternativo de solución de conflictos, desde una visión en el escenario de la contratación estatal y la percepción y falta de apoyo en el ámbito de lo cultural.

Asimismo, desde criterios diferentes pero complementarios, se revisa la evolución de los derechos humanos gestados en el orden interno de los Estados y elevados a rango constitucional, hoy en día inherentes a los sistemas jurídicos internacionales. De ello dan evidencia los artículos "Defensores y defensoras de derechos humanos, obstáculo en la lucha antiterrorista", cuyo autor es José Guillermo Carrillo-Ballesteros, y "El control de convencionalidad y la protección de los derechos humanos en Colombia", escrito por Lizandro Alfonso Cabrera-Suárez, profesores e investigadores de la Universidad Cooperativa de Colombia, el primero de Bucaramanga y el segundo de Cali.

Otro tema de interés es el concerniente a la discusión filosófica entre los juristas de la posmodernidad frente a las relaciones conceptuales entre derecho y moral. El investigador Ariel Fernando Rincón-Almeyda, decano de la Facultad de Derecho de Uniciencia, nos permite disponer de este análisis con su artículo "Metaética de la Corte Suprema de Justicia de la Nación Argentina en la jurisprudencia de la dosis personal". 
Con enfoque interdisciplinario, se publica el artículo "Cambio climático y adaptación para la región los Santanderes: percepciones y consideraciones desde el marco legal", en el que se examina el derecho desde la perspectiva de la mitigación del impacto ambiental y la adaptación de una región a los cambios climáticos a partir de políticas públicas implementadas sobre el tema. Sus autoras son Julia Teresa Bedoya-Mashuth y Melva Salazar de Cardona, investigadoras del Centro de Investigaciones del Medio Ambiente y Desarrollo (CIMAD), siendo además la primera de ellas decana nacional de las facultades de Medicina Veterinaria y Zootecnia de la Universidad Cooperativa de Colombia.

Se hace difícil conceptuar sobre si uno u otro artículo es más relevante. Todos ellos contienen calidad en su contenido y, desde sus propias complejidades, se construyeron en un lenguaje accesible para diversos lectores interesados en el campo académico y sociojurídico, remitiéndonos a problemas actuales y permitiéndonos encontrar la pertinencia significativa a los temas investigados. Por ello, y reiterando lo dicho al inicio de este escrito, aquí se está consolidando la labor responsable de un grupo de investigadores y pedagogos a quienes agradecemos su esfuerzo y voluntad al permitirnos publicar en nuestra revista el resultado de su trabajo.

Además, el reconocimiento lo extendemos a los miembros de los comités editorial y científico, quienes aceptaron continuar apoyando con su sapiencia esta labor de publicitar los resultados de investigaciones. También a los árbitros, quienes dedicaron tiempo para valorar el trabajo ajeno, pero que, al sentirlo como suyo, ayudaron a mejorar lo hecho con sus comentarios constructivos. También agradecemos el apoyo de la editora y de las demás personas que hicieron posible cumplirles a ustedes, nuestros lectores, con el número 19. Como ustedes son la razón de ser de esta publicación, nos acompaña el deseo de mejorarla y seguir propagando a través de este medio escritos de la más alta calidad académica y científica. Una responsabilidad imperante si se tiene en cuenta que el programa cumplió veinte años apoyando la profesionalización de los colombianos.

Marien Yolanda Correa Corredor

Decana de la Facultad de Derecho

Universidad Cooperativa de Colombia

Sede Bucaramanga 
$\mathrm{W}$ e who are dedicated to the study of the law cannot abandon the conviction that, in the midst of social conflicts and changes in the world which we can neither ignore nor remain indifferent to, there is a need to intensify research in response to a dynamic and changing society through proposals for modernizing the legal order in accordance with new realities. To this end, during the first semester of 2014, we are publishing issue number 19 of the DIXI journal as part of the commemoration of the twentieth anniversary of the founding of the law faculty at the Bucaramanga campus of the Universidad Cooperativa de Colombia.

We believe that this issue contains valuable articles that are the fruit of careful and selfless study by their authors, who understand the importance of transformations in the world of knowledge and accept that the legal science must be seen as crosscutting to diverse disciplines in response to the problems of daily life. These authors know that research along with teaching helps to de-mythologize the idea that the law is only a matter of rules. On the contrary, they conceive of it in the social, economic, political and cultural contexts that determine its creation. We aim for our respected readers to enjoy diverse documents written with professionalism and as a contribution to the reason for being of higher education: to deepen knowledge.

As an international researcher and collaborator of the journal, we have Gabriela Ulas of the Universidad de Buenos Aires and the Universidad de Belgrano, both in Buenos Aires (Argentina). Her article "La responsabilidad del profesional en los delitos tributarios y la imputación objetiva" ("The Responsibility of Professionals in Tax Crimes and Objective Imputation") constitutes a careful analysis of the role of legal professionals in response to tax evasion and tax crimes.

In the text entitled "Estado actual de los mecanismos para la solución de conflictos contractuales en el Estado colombiano" ("Current Status of Mechanisms for Resolving Contractual Conflicts in the Colombian State"), Lina Marcela Reyes-Sarmiento and Sara Patricia Guzmán-Suárez, researchers from the Bucaramanga campus of the Universidad Pontificia Bolivariana, analyze conciliation, an alternate conflict resolution mechanism, from the perspective of state contracting along with perception and lack of support in the cultural realm.

Based on different but complementary criteria, the evolution of human rights is examined as they have developed in the internal organization of states and been raised to the constitutional level to become inherent to international legal systems. This is found in the articles entitled "Defensores y defensoras de derechos humanos, obstáculo en la lucha antiterrorista" ("Men and Women Human Rights Defenders, an Obstacle in the Fight against Terrorism"), written by José Guillermo Carrillo-Ballesteros, and "El control de convencionalidad y la protección de los derechos humanos en Colombia" ("The Control of Conventionality and Human Rights Protection in Colombia"), by Lizandro Alfonso Cabrera-Suárez, professors and researchers at the Universidad Cooperativa de Colombia, the former in Bucaramanga and the latter in Cali.

Another topic of interest concerns philosophical discussion among postmodern jurists about the conceptual relationships between law and morality. Researcher Ariel Fernando Rincón-Almeyda, Dean of the Law Faculty of Uniciencia, carries out this analysis in his article "Metaética de la Corte Suprema de Justicia de la Nación Argentina 
en la jurisprudencia de la dosis personal" ("Meta-ethics of the Supreme Court of Justice of the Argentine Nation in Jurisprudence Regarding the Personal Dose").

The article entitled "Cambio climático y adaptación para la región de los Santanderes: percepciones y consideraciones desde el marco legal" ("Climate Change and Adaptation for the Region of the Santanderes: Perceptions and Considerations from the Legal Framework"), is written from an interdisciplinary approach. It examines the law from a perspective of environmental impact mitigation and adaptation of a particular region to climate change based on public policies implemented in this field. It was written by Julia Teresa Bedoya-Mashuth and Melva Salazar de Cardona, researchers from the Research Center on the Environment and Development (CIMAD from its Spanish acronym), the former being National Dean of the Veterinary and Zootechnical faculties of the Universidad Cooperativa de Colombia.

It is difficult to say which article is the most relevant. They all have quality content and, despite their complexities, make use of a language accessible to diverse readers interested in the academic and socio-legal field. While making reference to current problems, they enable us to find significant relevance to the research topics. Therefore, and reiterating what was said at the beginning of this writing, this issue is a consolidation of responsible work by a group of researchers and professors whom we thank for their efforts and willingness to allow us to publish the results of their work in our journal.

We also wish to extend our recognition to the members of the editorial and scientific committees, who have agreed to continue to contribute their knowledge to the work of publishing research results. Also the reviewers, who contributed their time to assess the work of others, but in treating it as if it were their own, helped to improve the articles with their constructive comments. We also wish to express our appreciation for the support of the editor and others who made it possible for us to fulfill our promise to you, our readers, with number 19. Because you are the reason for being of this publication, and you also accompany us in improving and continuing to disseminate articles of the highest academic and scientific quality through this medium. That is an overriding responsibility at a time when this program celebrates 20 years of supporting the professionalization of Colombians.

\section{Marien Yolanda Correa Corredor}

Dean of the Law Faculty

Universidad Cooperativa de Colombia

Bucaramanga campus 